\title{
A comparison of biological, molecular and enzymatic markers to investigate variability within Microdochium nivale (Fries) Samuels and Hallett
}

\author{
N Maurin 1*, HN Rezanoor 2, Z Lamkadmi ${ }^{1}$, A Somé ${ }^{1}, \mathrm{P}$ Nicholson 2 \\ 1 INRA, station de pathologie végétale, BP 29, F35650 Le Rheu, France; \\ 2 Cambridge Laboratory, John Innes Centre, Colney Lane, Norwich NR4 7UJ, UK
}

(Received 2 September 1994; accepted 24 February 1995)

Summary - The variation among isolates of Microdochium nivale obtained from a range of hosts and locations in Europe was investigated on the basis of conidial morphology, restriction fragment length polymorphisms (RFLPs) of the internal transcribed spacer (ITS) region of ribosomal DNA (rDNA), esterase profiles, aggressiveness on wheat seedlings and perithecial production. One homogeneous group was resolved on the basis of esterase profiles and RFLPS of the ITS region of rDNA. The isolates within this group possessed ITS profiles identical to reference isolates of var majus from other workers and therefore were assigned to var majus. The isolates within this homogeneous var majus grouping were obtained from a range of locations throughout Europe, demonstrating that it is not restricted to the United Kingdom. Nineteen esterase profiles and 2 ITS profiles were detected among the remaining isolates, suggesting that this grouping may be comprised of further sub-groups. The results demonstrated that several isolate types may exist at a single location and that pathogenicity to wheat seedlings was not related to any of the traits analysed.

Microdochium nivale / cereal / RFLP / internal transcribed spacer

Résumé - Comparaison de marqueurs biologiques, moléculaires et enzymatiques pour l'analyse de la variabilité chez Microdochium nivale. Les variations au sein d'une collection de souches européennes de Microdochium nivale isolées de plusieurs hôtes sont étudiées sur la base de la morphologie des conidies, des profils d'estérases et de RFLP de la région des ITS de l'ADN ribosomique, de l'agressivité sur des plantules de blé et de la capacité à produire des périthèces in vitro. Un groupe homogène est différencié à la fois par les profils d'estérases et les RFLP des ITS de I'ADN-r. Les isolats de ce groupe possèdent des profils d'ITS identiques aux isolats de référence de la variété majus utilisés par d'autres auteurs et sont, par conséquent, assignés à la variété majus. Les isolats à lintérieur du groupe homogène majus ont été collectés à travers l'Europe, ce qui démontre que ce groupe n'est pas restreint au Royaume-Uni. Parallèlement, 19 profils d'estérases et 2 profils d'ITS sont observés parmi le reste des isolats, ce qui suggère que ce groupe pourrait être constitué de plusieurs autres sous-groupes. Les résultats démontrent que les 2 types d'isolats coexistent dans un même lieu et que l'agressivité sur plantules de blé n'est liée à aucun autre caractère étudié.

Microdochium nivale / céréales / RFLP / internal transcribed spacer

${ }^{*}$ Correspondence and reprints 


\section{INTRODUCTION}

Microdochium nivale (Fries) Samuels and Hallett (teleomorph Monographella nivalis (Schaffnit) Müller) is distributed worldwide and causes snow mould of cereals and turfgrasses (Cook, 1981), foot rot (Harris, 1986; Pettitt et al, 1993) and head blight diseases of cereals when high humidity and low temperature occur during anthesis (Cassini, 1981; Cook, 1981). It has been recorded as one of the dominant pathogen species identified from wheat samples in Western Europe (Duben and Fehrmann, 1979; Parry, 1990; Daamen et al, 1991; Maurin and Chénet, 1993), and resistance tests with artificial inoculation have been developed in order to assess levels of resistance of cereals to $M$ nivale (Bruehl, 1982; Litschko et al, 1988; Miedaner et al, 1993). Two varieties have been distinguished, on the basis of conidial characteristics, within $M$ nivale (Wollenweber and Reinking, 1935). These are $M$ nivale var nivale (Fries) Samuels and Hallett and $M$ nivale var majus (Wollenw) Samuels and Hallet (Gams and Müller, 1980; Gerlach and Nirenberg, 1982).

Despite its range of hosts (small grain cereals, lawn and turf grass) and the extent of its distribution (Australia, China, North America and Europe), little attention has been paid to the variability of the pathogen. Recently, Lees et al (1995) used random amplification of polymorphic DNA (RAPD) analysis to study variability within $M$ nivale isolates. A distinct homogeneous subgroup, correlating broadly to $M$ nivale var majus was identified along with a heterogeneous grouping which related to $M$ nivale var nivale. Nevertheless, this work was restricted to British isolates originating from wheat only. The present work was undertaken to analyse the variation among isolates from a broader range of hosts and locations in order to test the variation of the fungus across Europe using a set of complementary traits. Esterase profiles, ITS-rDNA (internal transcribed spacer-ribosomal DNA) digestion profiles, conidial morphology and aggressiveness as well as perithecial production in vitro were considered in order to establish possible connections between morphological, biological and genetic variation within a European collection of $M$ nivale.

\section{MATERIALS AND METHODS}

\section{Origin and maintenance of fungal isolates}

The isolates of $M$ nivale used in this study were obtained from a number of European countries and a range of hosts (table 1). All isolates were derived from single conidia and maintained on SNA medium (Nirenberg, 1981) slants at $4^{\circ} \mathrm{C}$ and subcultured each year for preservation.

Isolates $\mathrm{N} 14$ ( $M$ nivale var nivale) and N15 ( $M$ nivale var majus) were a kind gift from $\mathrm{H}$ Nirenberg (BBA collection, Berlin), and were used as taxonomic references of nivale and majus varieties. For the restriction enzyme digestion of ITS-rDNA, other isolates, B37, B38 and B101 ( $M$ nivale var nivale) and $\mathrm{B} 02, \mathrm{~B} 05, \mathrm{~B} 10, \mathrm{~B} 18$ and $\mathrm{B} 27$ ( $M$ nivale var majus), were added in order to compare with the groupings identified using RAPDs in the study of Lees et al (1995).

\section{Conidial morphology}

All single conidial isolates were plated on potato dextrose agar (PDA) and incubated at $20^{\circ} \mathrm{C}$ for $3 \mathrm{~d}$ in the dark followed by $6 \mathrm{~d}$ at $8^{\circ} \mathrm{C}$ under a $18 \mathrm{~h} / 6 \mathrm{~h}$ near ultraviolet/dark regime.

Twenty-five conidia of each isolate were examined and an average spore length, width and number of septa was calculated. Isolates were tentatively assigned to 1 of the 2 varieties on the basis of these characters as described by Gerlach and Nirenberg (1982).

\section{Protein extraction and polyacrylamide gels}

Mycelial explants of single conidial cultures were grown in a Tanaka liquid medium (Ou, 1972) containing $10 \mathrm{~g}$ glucose at $20^{\circ} \mathrm{C}$ in the dark. After $7 \mathrm{~d}$ incubation, the fungal mats were recovered by vacuum filtration using a No 1 Whatman filter paper, rinsed twice with distilled water and then freeze-dried. The proteins were extracted by the method of Some and Tivoli (1993): $100 \mathrm{mg}$ freeze-dried mycelium was added to $100 \mathrm{mg}$ Fontainebleau sand and $100 \mathrm{mg}$ insoluble polyvinylpyrrolidone (PVP) in $1 \mathrm{ml}$ extraction buffer at $4^{\circ} \mathrm{C}$ and ground in a cool mortar for $15 \mathrm{~min}$. The extraction buffer $\mathrm{pH} 7$ contained $10 \mathrm{mM}$ Tris, $1 \mathrm{mM}$ EDTA, $3 \mathrm{mM}$ 2-mercaptoethanol, and $1 \mathrm{mM}$ cysteine. After centrifugation at $13000 \mathrm{~g}$ for $10 \mathrm{~min}$, glycerol was added to the supernatant to a total of $10 \%$ of the final volume and the protein-rich solution was stored at $20^{\circ} \mathrm{C}$ or was applied to a $9 \%$ polyacrylamide gel for electrophoresis using the Laemmli technique (Laemmli, 1970). Each well contained $20 \mu \mathrm{l}$ of extracted solution and electrophoresis was carried out in a slab gel unit SE 280 (Hoefer Scientific Instruments) at $200 \mathrm{~V}$ at $4^{\circ} \mathrm{C}$ for $2 \mathrm{~h}$.

Esterases were detected using a modified version of the method described by Siciliano and Shaw (1976). Fast blue RR salts $(50 \mathrm{mg})$ were dissolved in $50 \mathrm{ml}$ of $0.1 \mathrm{M}$ phosphate buffer $(\mathrm{pH} 6)$ at $37^{\circ} \mathrm{C}$. After filtration through a Whatman No 1 filter paper, $1 \mathrm{ml}$ acetone containing $20 \mathrm{mg} \alpha$-naphthyl acetate and $20 \mathrm{mg}$ $\beta$-naphthyl acetate was added. After a few seconds of 
Table I. Origin, conidial morphology, production of perithecia, esterase patterns and ITS groups of isolates of Microdochium nivale.

\begin{tabular}{|c|c|c|c|c|c|c|c|}
\hline Isolate code & Original code & Origin & Host & $\begin{array}{l}\text { Perithecial } \\
\text { production }\end{array}$ & $\begin{array}{l}\text { Esterase } \\
\text { profile }\end{array}$ & $I T S$ a & $\begin{array}{c}\text { Varietal } \\
\text { designation } \mathrm{b}\end{array}$ \\
\hline N2 & Fn 2 & France & Durum wheat & + & nd $c$ & $2 b$ & nivale \\
\hline N3 & Fn 3 & France & Durum wheat & - & D & $2 a$ & nivale \\
\hline N5 & F 75 & Switzerland & Wheat & + & $E$ & $2 a$ & nivale \\
\hline N7 & F 105 & Switzerland & Rye & - & $F$ & $2 a$ & nivale \\
\hline N8 & F 106 & Switzerland & Wheat & - & $G$ & $2 a$ & nivale \\
\hline N10 & F 129 & Switzerland & Barley & - & $A$ & 1 & majus \\
\hline N12 & 131 & Netherlands & Wheat & - & $A$ & 1 & majus \\
\hline N14 & 64624 & Germany & Turf grass & - & B & $2 a$ & nivale \\
\hline N15 & 64720 & Germany & Durum wheat & + & $A$ & 1 & majus \\
\hline N18 & RPA F 74 & France & Turf grass & - & $\mathrm{H}$ & $2 a$ & nivale \\
\hline N20 & CBS 167.57 & - & - & - & I & $2 b$ & nivale \\
\hline N22 & FN 22 & France & Wheat & + & $J$ & $2 b$ & nivale \\
\hline N25 & FN 25 & France & Wheat & - & $\mathrm{K}$ & $2 b$ & nivale \\
\hline N32 & FN 32 & France & Wheat & - & $\mathrm{C}$ & $2 b$ & nivale \\
\hline N36 & FN 36 & France & Wheat & + & A & 1 & majus \\
\hline N45 & UPM/637 & Belgium & Turf grass & - & $\mathrm{L}$ & $2 b$ & nivale \\
\hline N48 & FN 48 & France & Durum wheat & + & $A$ & 1 & majus \\
\hline N58 & FN 58 & France & Durum wheat & + & $M$ & $2 b$ & nivale \\
\hline N62 & FN 62 & France & Durum wheat & + & $A$ & 1 & majus \\
\hline N68 & $15 / 85$ & Poland & Turf grass & - & $N$ & $2 b$ & nivale \\
\hline N71 & $2 M 3 / 86$ & Poland & Rye & - & 0 & $2 a$ & nivale \\
\hline N74 & $1969 / 86$ & Poland & Rye & - & $P$ & $2 b$ & nivale \\
\hline N75 & FN 75 & France & Wheat & + & $Q$ & $2 b$ & nivale \\
\hline N81 & FN 81 & France & Wheat & + & $\mathrm{R}$ & $2 b$ & nivale \\
\hline N88 & FN 88 & France & Wheat & - & $\mathrm{S}$ & $2 b$ & nivale \\
\hline N9O & FN 90 & France & Wheat & - & $\mathrm{C}$ & $2 b$ & nivale \\
\hline N99 & FN 99 & France & Wheat & + & A & 1 & majus \\
\hline N101 & FN 101 & France & Wheat & + & $\mathrm{T}$ & $2 a$ & nivale \\
\hline
\end{tabular}

\section{Additional isolates}

$\begin{array}{llllllll}\text { B 02 } & \text { Mn 02 } & \text { UK } & \text { Wheat } & - & \text { nd } & 1 & \text { majus } \\ \text { B 05 } & \text { Mn 05 } & \text { UK } & \text { Wheat } & + & \text { nd } & 1 & \text { majus } \\ \text { B 10 } & \text { Mn 10 } & \text { UK } & \text { Wheat } & + & \text { nd } & 1 & \text { majus } \\ \text { B 18 } & \text { Mn 18 } & \text { UK } & \text { Wheat } & - & \text { nd } & 1 & \text { majus } \\ \text { B 27 } & \text { Mn 27 } & \text { UK } & \text { Wheat } & - & \text { nd } & 1 & \text { majus } \\ \text { B 37 } & \text { Mn 37 } & \text { UK } & \text { Wheat } & + & \text { nd } & 2 a & \text { nivale } \\ \text { B 38 } & \text { Mn 38 } & \text { UK } & \text { Wheat } & - & \text { nd } & \text { 2b } & \text { nivale } \\ \text { B 101 } & \text { Mn 101 } & \text { UK } & \text { Wheat } & + & \text { nd } & \text { 2a } & \text { nivale }\end{array}$

a Profile of amplified products of ITS rDNA after digestion by Cfo I and Rsa I; b varietal designation based upon ITS and esterase profiles; ${ }^{c}$ not determined.

agitation, the gel was incubated in this mixture for 30 min at $37^{\circ} \mathrm{C}$ in the dark, and then rinsed with water and fixed with $10 \%$ acetic acid.

\section{DNA extraction}

Mycelium was scraped from the surface of 4-day-old colonies on PDA and used to inoculate $50 \mathrm{ml}$ potato dextrose broth. Cultures were incubated at ambient temperature on an orbital shaker in the dark for $7 \mathrm{~d}$. Mycelium, harvested by filtration onto Whatman No 1 filter paper disks, was freeze-dried and then ground in a mill to a fine powder using 2 steel balls in a $25 \mathrm{ml}$ tube shaken vigorously for $4 \mathrm{~min}$. DNA was extracted and purified by the method of O'Dell et al (1989), except for the initial incubation step, which was carried out at $65^{\circ} \mathrm{C}$. DNA was diluted to $10 \mathrm{ng} / \mu \mathrm{l}$ for use in amplification reactions. 


\section{Primer and amplification conditions for PCR}

Primers ITS4 and ITS5 (White et al, 1990) were used to amplify the (ITS) region between the $18 \mathrm{~S}$ and $25 \mathrm{~S}$ rDNA coding sequences. Amplification reactions were performed in a volume of $50 \mu \mathrm{l}$ containing $10 \mathrm{ng}$ genomic template DNA. The reaction buffer consisted of $100 \mu \mathrm{M}$ each of dATP, dCTP, dGTP and dTTP, $200 \mathrm{nM}$ each of ITS4 and ITS5, and 0.8 units of Taq polymerase (Boehringer Mannheim Ltd), in $10 \mathrm{nM}$ Tris, $\mathrm{HCl}\left(\mathrm{pH}\right.$ 8.3), $1.5 \mathrm{mM} \mathrm{MgCl}_{2}, 50 \mathrm{mM} \mathrm{KCl}, 100 \mu \mathrm{g} \mathrm{ml}^{-1}$ gelatine, $0.05 \%$ Tween 20 , and $0.05 \%$ Nonidet P-40. Reaction mixtures were overlaid with mineral oil prior to PCR.

Amplification was performed in a Perkin Elmer Cetus DNA Thermal Cycler programmed for 35 cycles of $30 \mathrm{~s}$ at $95^{\circ} \mathrm{C}, 1 \mathrm{~min}$ at $50^{\circ} \mathrm{C}$ and $2 \mathrm{~min}$ at $72^{\circ} \mathrm{C}$ using the fastest possible transitions between temperatures. A final extension step of $72^{\circ} \mathrm{C}$ for $5 \mathrm{~min}$ was included in the program followed by cooling to $4^{\circ} \mathrm{C}$ until recovery of the samples. Aliquots $(10 \mu \mathrm{l})$ of amplification products were electrophoresed through $1.5 \%$ agarose gels and detected by staining with ethidium bromide and visualised on a UV transilluminator.

\section{Restriction enzyme digestion}

PCR products were used directly for restriction enzyme digestion. The digestions were performed in a volume of $30 \mu \mathrm{l}$ containing $6 \mu \mathrm{l}$ of PCR amplification product and 6 units of enzyme. Enzyme-digested DNA was run through $2 \%$ agarose gels stained with ethidium bromide, and visualized and photographed under UV light. Ten restriction enzymes (Cla I, Cfo I, Dde I, Eco R V, Nde I, Pst I, Pvu I, Rsa I, Taq I and Xho I) were used to digest the ITS region.

\section{Aggressiveness}

Fifty seedlings per isolate of the wheat cultivar CampRémy were inoculated using a $5 \mathrm{~mm}$ agar disc from the margin of a 3-day-old colony, placed at the base of the seedlings at the 2-leaf stage and held in position by a ribbon of Parafilm (American National Can). After incubation for 1 month in a growth cabinet at $10^{\circ} \mathrm{C}$ day and $5^{\circ} \mathrm{C}$ night under a $16 \mathrm{~h}$ photoperiod, disease index (DI) was determined using the following $0-6$ scale: 0 no symptoms; 1 slight lesion on 1 sheath; 2 lesion on 1 sheath only or 2 slight lesions on 2 sheaths; 3 one sheath entirely necrotic; 4 one sheath entirely necrotic and lesion on other sheath; 5 two sheaths entirely necrotic; 6 more than 2 sheaths entirely necrotic.

\section{Production of perithecia in vitro}

Straw segments $(10 \mathrm{~mm})$ of wheat were sterilized by autoclaving 3 times at $121^{\circ} \mathrm{C}$ for $20 \mathrm{~min}$ with $24 \mathrm{~h}$ between each sterilisation. Straws were placed with their lengths touching in Petri dishes containing PDA and a plug of mycelium from a single conidial isolate of $M$ nivale was placed next to the straw. Plates were incubated at $15^{\circ} \mathrm{C}$ for 4 weeks and the presence of fertile perithecia recorded by examining the colony under a binocular microscope $(x 40)$.

\section{RESULTS}

\section{Conidial morphology}

Conidial morphology was examined and found to differ among isolates in a manner similar to that described by Gerlach and Nirenberg (1982). According to these authors, $M$ nivale var nivale is characterized by the presence of conidia mostly $1(0-3)$, exceptionally $4-7$ septate, measuring $16 \mu \mathrm{m}$ long and $2.8 \mu \mathrm{m}$ wide. $M$ nivale var majus is distinguished by wider, predominantly $3(1-7)$ septate conidia measuring $26 \times 5.3 \mu \mathrm{m}$. Nevertheless, the conidial size varies considerably and ranges from $10 \times 2.4 \mu \mathrm{m}$ to $25 \times 3.3 \mu \mathrm{m}$ for $M$ nivale var nivale and from $18 \times 5.3 \mu \mathrm{m}$ to $29 \times 5.7 \mu \mathrm{m}$ for $M$ nivale var majus.

In this study, the average number of septa, conidial length and width were distributed continuously in the range 2.4-6.0 septa, 3.8-6.8 $\mu \mathrm{m}$ and 17.4-41.2 $\mu \mathrm{m}$, respectively (table II). Statistical analysis of the data using PCA (principal component analysis) showed no distinct groups of isolates along the first axis, accounting for $75 \%$ of the total variance. Hierarchical clustering yielded 2 classes with low interclass inertia $(68 \%)$, showing that the morphological characteristics used could not be used to assign isolates unambiguously to 1 group or the other. Because of the difficulty of prioritizing these characters, no further attempt was made to designate variety on the basis of morphological markers.

\section{Restriction fragment length polymorphism in enzymatically amplified ribosomal DNA}

The ITS region amplified by primer pair ITS 4 and ITS5 was approximately $580 \mathrm{bp}$ long for all the isolates of $M$ nivale. The ITS-rDNA was not digested by the enzymes Cla I, Dde I, Eco R V, Nde I, Pst I, Pvu I, Taq I and Xho I, but length variations were detected after digestion with enzymes Cfo I and Rsa I (fig 1) and could be explained by the gain or loss, in some samples, of a single restriction site. 
Table II. Conidial morphology (number of septa, conidial width and length) and aggressiveness (disease index) of 28 isolates of Microdochium nivale.

\begin{tabular}{|c|c|c|c|c|}
\hline Isolate & Number of septa a & Conidial width a $(\mu \mathrm{m})$ & Conidial length a $(\mu \mathrm{m})$ & Disease index ${ }^{b}$ \\
\hline N2 & $2.45 \pm 0.5$ & $3.8 \pm 0.6$ & $18.8 \pm 2.1$ & $3.50 \pm 0.50$ \\
\hline N3 & $2.7 \pm 0.4$ & $4.1 \pm 0.4$ & $19.4 \pm 2.0$ & $2.39 \pm 0.17$ \\
\hline N5 & $2.6 \pm 0.5$ & $5.6 \pm 0.6$ & $20.0 \pm 2.6$ & $2.72 \pm 0.53$ \\
\hline N7 & $3.8 \pm 0.6$ & $5.0 \pm 0.6$ & $25.8 \pm 2.8$ & $1.96 \pm 0.46$ \\
\hline N8 & $4.2 \pm 0.7$ & $4.8 \pm 0.6$ & $21.8 \pm 3.4$ & $1.58 \pm 0.15$ \\
\hline N10 & $2.35 \pm 0.4$ & $4.1 \pm 0.4$ & $26.4 \pm 1.2$ & $2.04 \pm 0.47$ \\
\hline N12 & $6.0 \pm 0.7$ & $6.4 \pm 0.8$ & $41.2 \pm 3.0$ & $1.66 \pm 0.27$ \\
\hline N14 & $2.35 \pm 0.6$ & $5.0 \pm 0.7$ & $20.4 \pm 2.9$ & $2.14 \pm 0.28$ \\
\hline N15 & $5.1 \pm 0.8$ & $6.8 \pm 0.9$ & $31.6 \pm 3.4$ & $2.94 \pm 0.49$ \\
\hline N18 & $3.75 \pm 0.7$ & $4.8 \pm 0.6$ & $23.4 \pm 1.8$ & $2.28 \pm 0.17$ \\
\hline N2O & $2.8 \pm 0.6$ & $5.6 \pm 0.6$ & $23.6 \pm 4.4$ & $0.74 \pm 0.21$ \\
\hline N22 & $2.75 \pm 0.5$ & $5.2 \pm 0.6$ & $24.6 \pm 2.6$ & $2.04 \pm 0.21$ \\
\hline N25 & $3.15 \pm 0.4$ & $4.4 \pm 0.4$ & $17.4 \pm 1.8$ & $2.38 \pm 0.33$ \\
\hline N32 & $3.05 \pm 0.3$ & $4.2 \pm 0.4$ & $17.8 \pm 1.8$ & $2.18 \pm 0.29$ \\
\hline N36 & $4.0 \pm 0.7$ & $6.4 \pm 0.8$ & $33.4 \pm 3.2$ & $1.78 \pm 0.33$ \\
\hline N45 & $2.5 \pm 0.4$ & $5.6 \pm 0.4$ & $17.9 \pm 1.6$ & $1.48 \pm 0.41$ \\
\hline N48 & $3.5 \pm 0.6$ & $6.4 \pm 0.6$ & $36.6 \pm 2.6$ & $2.26 \pm 0.39$ \\
\hline N58 & $2.55 \pm 0.3$ & $5.2 \pm 0.4$ & $21.8 \pm 3.0$ & $2.70 \pm 0.19$ \\
\hline N62 & $3.0 \pm 0.3$ & $5.6 \pm 0.2$ & $26.8 \pm 3.6$ & $2.14 \pm 0.39$ \\
\hline N68 & $2.35 \pm 0.5$ & $4.0 \pm 0.6$ & $18.2 \pm 2.4$ & $2.58 \pm 0.52$ \\
\hline N71 & $3.3 \pm 0.4$ & $5.4 \pm 0.4$ & $22.8 \pm 2.0$ & $0.48 \pm 0.23$ \\
\hline N74 & $3.0 \pm 0.6$ & $5.8 \pm 0.6$ & $29.2 \pm 4.4$ & $2.24 \pm 0.76$ \\
\hline N75 & $3.5 \pm 0.7$ & $5.6 \pm 0.8$ & $22.6 \pm 3.0$ & $2.36 \pm 0.31$ \\
\hline N81 & $3.85 \pm 0.6$ & $5.2 \pm 0.6$ & $22.4 \pm 2.2$ & $3.31 \pm 0.79$ \\
\hline N88 & $3.9 \pm 0.7$ & $5.2 \pm 0.6$ & $19.0 \pm 2.4$ & $2.08 \pm 0.21$ \\
\hline N90 & $3.3 \pm 0.4$ & $5.0 \pm 0.4$ & $22.2 \pm 3.2$ & $2.04 \pm 0.34$ \\
\hline N99 & $2.65 \pm 0.5$ & $6.0 \pm 0.4$ & $32.6 \pm 3.0$ & $2.18 \pm 0.27$ \\
\hline N101 & $3.0 \pm 0.7$ & $4.6 \pm 0.6$ & $20.4 \pm 1.8$ & $2.46 \pm 0.55$ \\
\hline
\end{tabular}

a Measurements for 25 conidia, means with standard error; ${ }^{b}$ disease index scale of $0-6$ (details of scale in text).

After digestion of the ITS-rDNAs with Rsa I, the isolates were split into 2 groups. Isolates N10, N12, N15, N36, N48, N62 and N99 constituted group 1 and were characterized by the presence of 2 DNA fragments (approximately 490 and $90 \mathrm{bp}$ ) resulting from the digestion by Rsa I at one restriction site. The ITS-rDNA of the remaining isolates (group 2) was not cut by Rsa I (fig $1 \mathrm{a}$ and $1 \mathrm{~b}$ ). Digestion of the ITS-rDNA with Cfo I produced 3 fragments (approximately 280 , 170 and $130 \mathrm{bp}$ ) in several isolates (N3, N5, N7, N8, N14, N18, N71 and N101) within group 2 (sub-group 2a) (fig 1c and 1d) whereas amplification products from all group 1 isolates and the remaining group 2 (sub-group $2 b$ ) isolates were cut by Cfo I, at a single site to produce 2 fragments (approximately 300 and 280 bp) (fig 1c and 1d).

The var majus reference isolate (N15) and 5 British isolates (B02, B05, B10, B18 and B27) were assigned to group 1 whereas the var nivale reference $(\mathrm{N} 14)$ and 3 British isolates (B37, B38 and $\mathrm{B} 101$ ) were assigned to sub-group $2 \mathrm{a}$.

\section{Electrophoresis protein patterns}

In a preliminary study (results not shown), electrophoresis was carried out on 8 isolates, including the N14 and N15 reference isolates, using several enzyme systems (esterases, phosphoglucoisomerase, phosphoglucomutase, polyphenoloxidase and superoxidedismutase). The esterase enzymes revealed considerable variation among isolates of $M$ nivale (fig 1 ) and was used on the full isolate set. Twenty clearly different esterase profiles were detected among the 27 isolates examined (table I). Only 2 profiles ( $A$ and $C$ ) were common to more than 1 isolate. Profile A was common to 7 isolates (N10, N12, 
a)

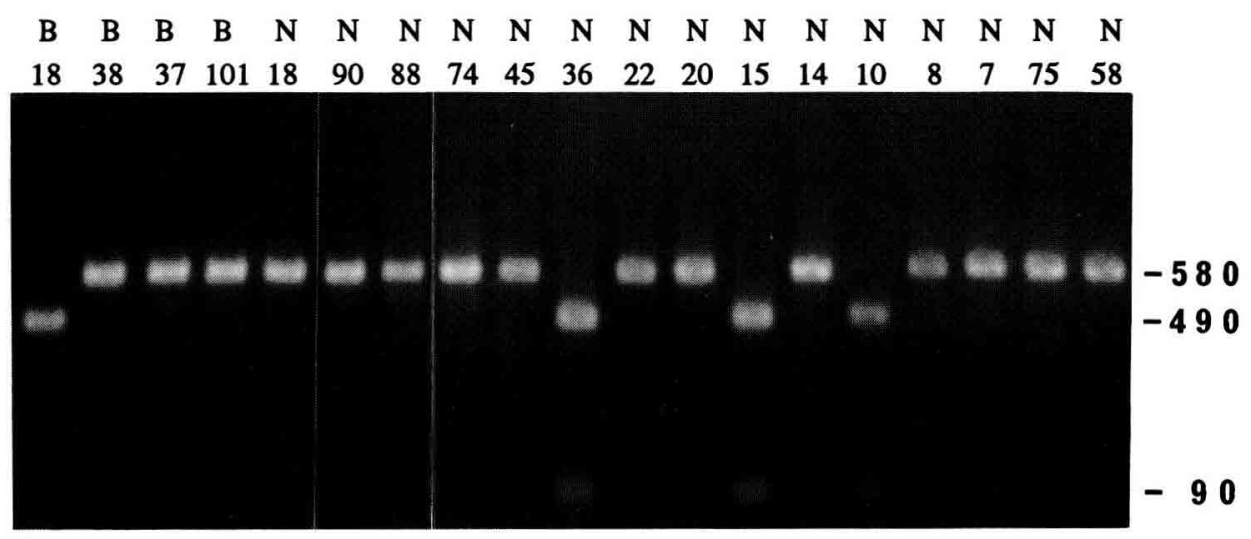

b)

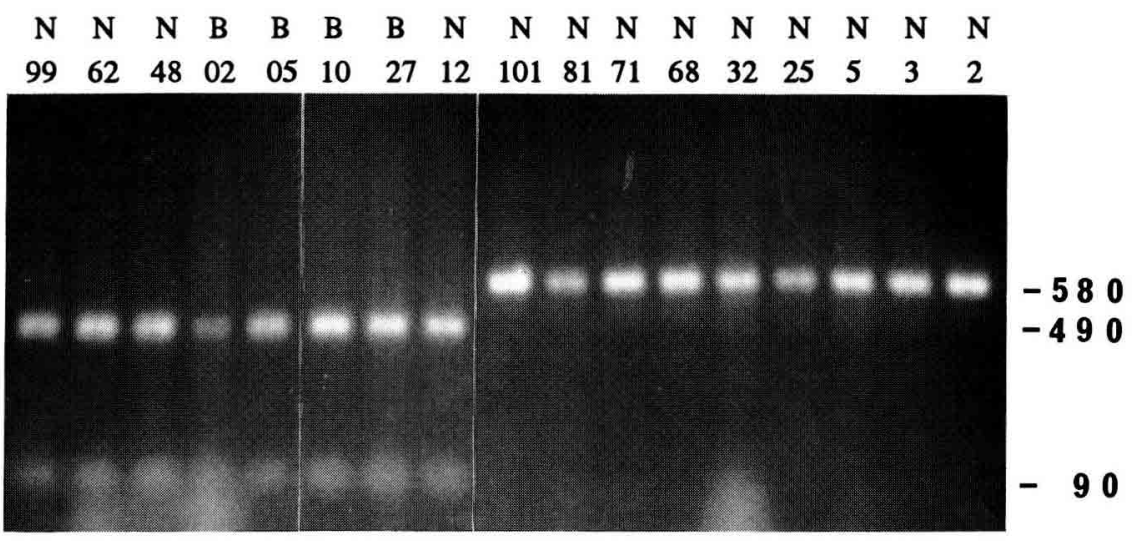

c)
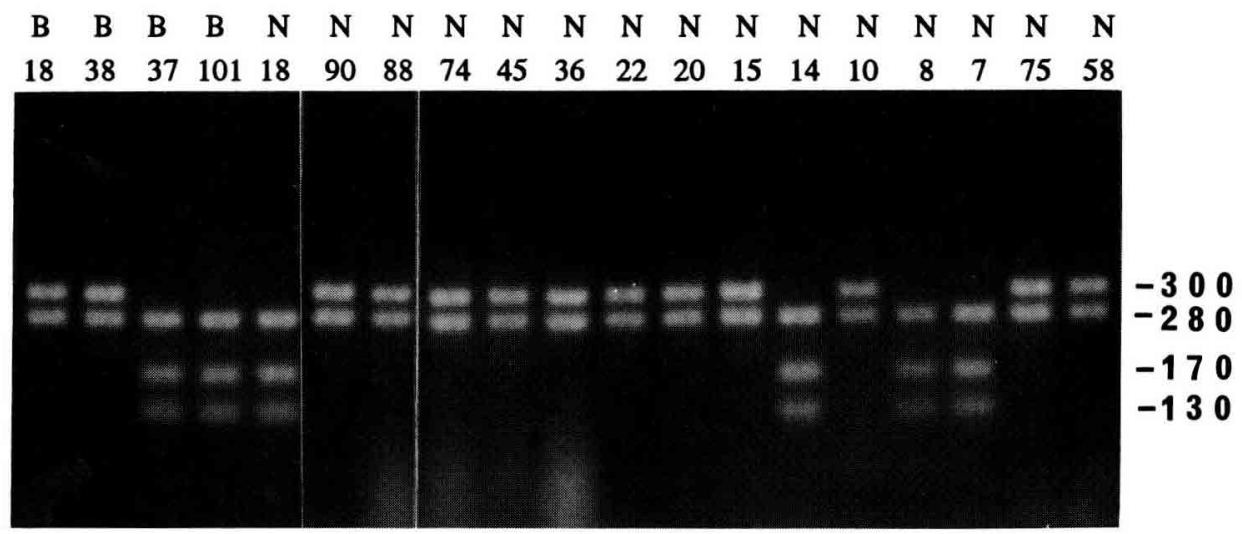

d)

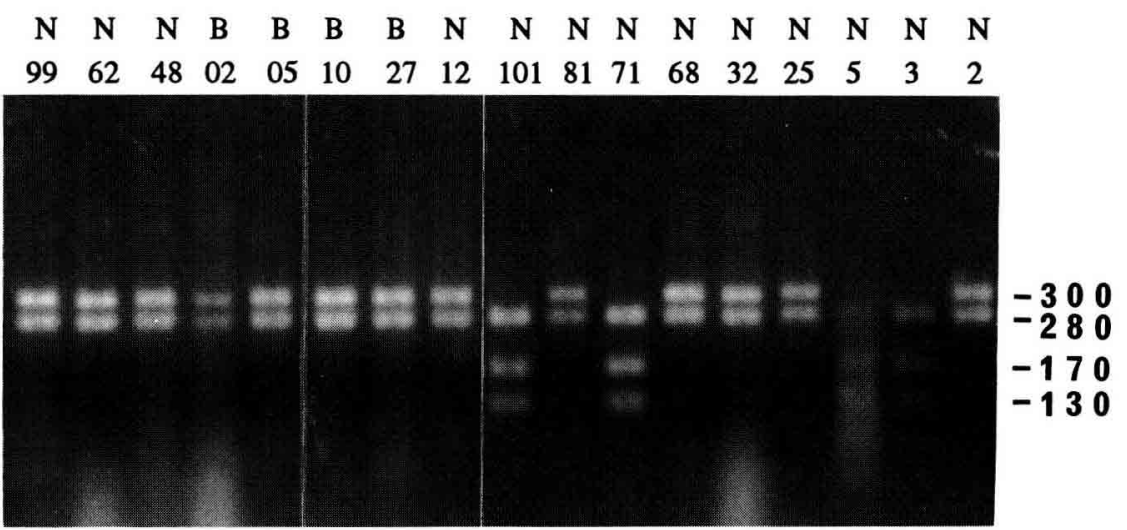

Fig 1. Agarose gel showing PCR-amplified ITS region of $r$-DNA of Microdochium nivale digested by restriction enzymes; a) and b) Rsa I: fragment sizes 490 and 90 bp, group 1; 580 bp (uncut) group 2; c) and d) Cfo I: fragment sizes 300 and 280 bp, groups 1 and $2 \mathrm{~b} ; 280,170$ and $130 \mathrm{bp}$, group $2 \mathrm{a}$. 


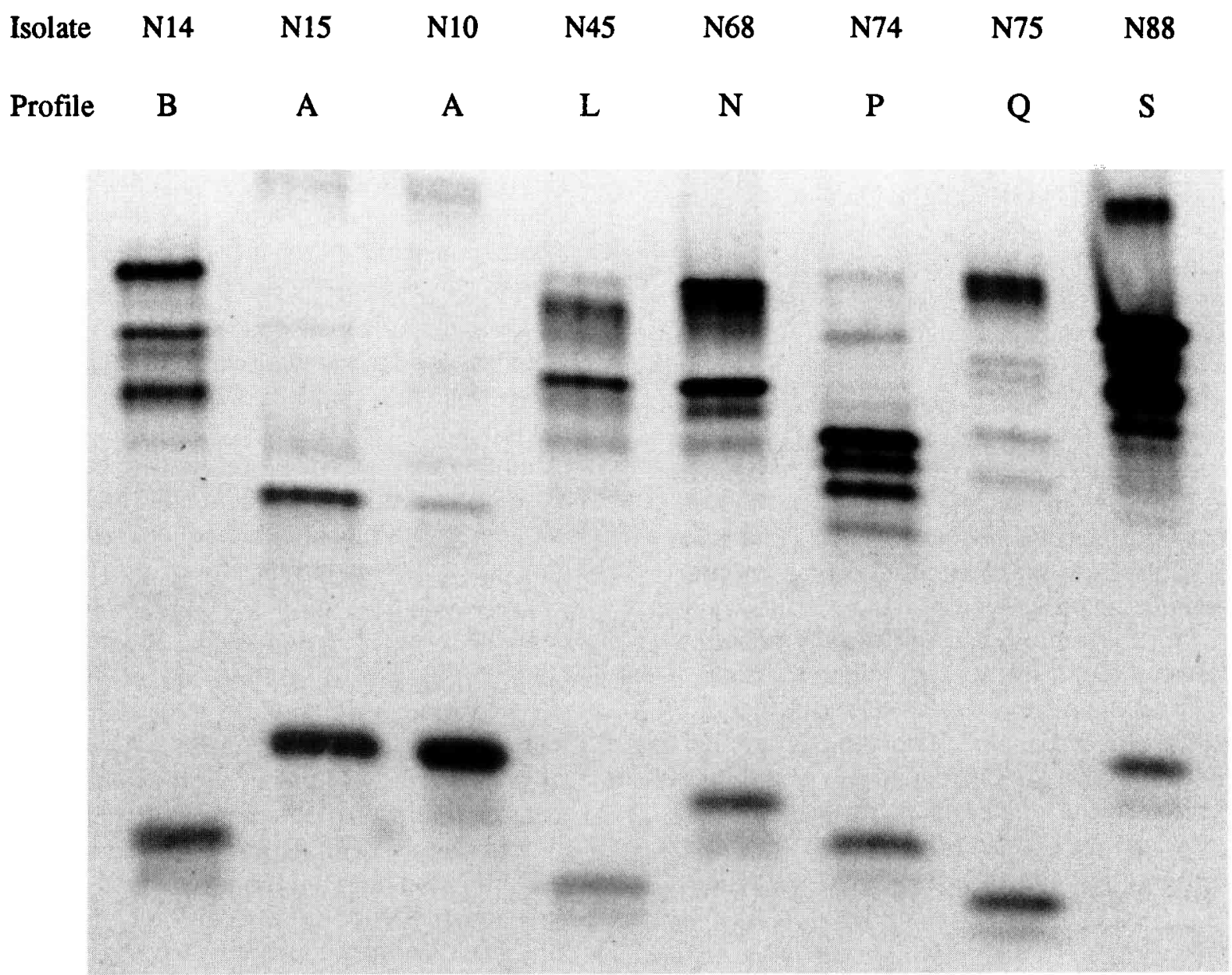

Fig 2. Examples of esterase profiles of isolates of Microdochium nivale.

N15, N36, N48, N62 and N99) isolated from 3 different cereal hosts and originating from a wide range of locations, including Switzerland, the Netherlands, Germany and France. Profile $C$ was shared by 2 French isolates from wheat, N32 and N90 (table I).

Interestingly, all isolates which possessed the esterase profile A also had the group 1 ITS profile, whereas the remaining isolates showing various esterase profiles ( $B$ to $T$ ) possessed the group 2 ITS profile.

\section{Aggressiveness}

According to the seedling test carried out in greenhouse conditions, all isolates were virulent on cultivar Camp-Rémy. The disease index (DI) ranged from 0.5 to 3.3 (table II), depending on the isolate, and significant differences were observed between the isolates. Isolates N20 and N71 were only slightly aggressive with a DI of less than 1 , while isolates N68, N58, N5, N15,
N81 and N2 were more aggressive with DIs above 2.5 .

No correlation appeared between pathogenicity and groupings whether according to esterase, ITS or conidial morphology. The isolates belonging to group 1 (esterase profile A) ranged from weakly aggressive (N12 and N36) to aggressive (N10, N62, N48 and N99). Isolate $\mathrm{N} 15$ was highly aggressive (DI 2.94). Isolates assigned to ITS sub-groups $2 a$ and $2 b$ were also distributed across the range of DI.

\section{Production of perithecia in vitro}

Twelve of the 28 isolates examined produced fertile perithecia on wheat straw in vivo (table I). Five of the 7 isolates with esterase profile $A$ and ITS-group 1 produced mature perithecia in vitro. Conversely, only 2 of the 8 ITS-sub-group $2 \mathrm{a}$ isolates and 5 of the 13 ITS-sub-group $2 b$ isolates produced perithecia in vitro. Thus, there was no clear correlation between the ability to produce perithecia in vitro and groupings. 


\section{DISCUSSION}

The aim of this study was to examine variation in a collection of European isolates of $M$ nivale from a number of countries and a range of hosts using different methods of characterization. The results indicate that $M$ nivale is highly variable but discrete sub-groups may be identified on the basis of isozyme and restriction profiles of the ITS region. However, these subgroups can hardly be correlated with the varieties described in the literature. According to Gerlach and Nirenberg (1982) it is possible to distinguish 2 varieties on the basis of classical taxonomic criteria. In the present study, variation for conidial traits was almost continuous and showed no correlation with one another. Therefore, the assignment of individual isolates to 1 of the 2 varieties was not readily possible, because of the difficulty of prioritizing the characters. These data show the limitations of the traditional taxonomy based on morphology and indicate that the conidial characters do not provide a reliable means of identifying members of homogeneous sub-groups within $M$ nivale.

RFLP (restriction fragment length polymorphism) analysis of the ITS indicated the presence of 3 groupings. One of them (group 1) included the var majus reference isolate from Germany $\mathrm{N} 15$, and the RAPD characterized var majus British isolates B02, B05, B10, B18 and B27. Esterase profiles appeared to be very polymorphic within $M$ nivale, and only 2 profiles were observed in more than 1 isolate. One of these, profile A, was present in the 7 ITS group 1 isolates.

It is thus possible to characterize the members of a sub-group within a wide range of European isolates of $M$ nivale using either RFLP ITS profiles or isozymes. Moreover, the ITS of all 48 RAPD-characterized isolates used by Lees et al (1995) have subsequently been examined in order to establish the correspondence of the groupings characterized by RAPD and RFLP of the ITS region. The results (not shown) indicated that the sub-group 1 as defined by ITS and isozyme profiles among European isolates correspond to the var majus as defined on the basis of RAPDs among British isolates. The majus group is widely distributed and is not restricted to the United Kingdom. It exists in all the European countries considered in this study, ie France, Germany, Poland and Switzerland.

The considerable polymorphism within the remaining isolates observed for esterase in the present work, and RAPDs in the work of Lees et al (1995), suggests that this may represent a diverse group, or may be comprised of further sub-groups. However, RFLP analysis of the ITS region revealed a single polymorphism for $\mathrm{Cfo} I$ among these isolates. In the absence of further information we have chosen to continue to treat this as a single heterogeneous group which we refer to as var nivale.

Variation for these characters was also detected at the field level. Two of 6 isolates (N48 and N62) from a single field were var majus while the remaining isolates (N58, N81, N88 and N90) differed in their esterase profiles ( $M, R, S$ and $C$ ) and aggressiveness on wheat seedlings. Thus it appears that a highly heterogeneous population may occur at the single field level.

All isolates from turf grass and rye were pathogenic on wheat and, in addition, all failed to produce perithecia in vitro. These observations concur with reports by Smith (1983), Harris (1986) and Litschko and Burpee (1987). All these isolates were assigned to var nivale on the basis of esterase and ITS rDNA profiles. It is interesting to note that, to date, no var majus isolates have been reported from turf grass, whereas both varieties may be found on wheat. Thus, the 2 forms may exist simultaneously in 1 ecological niche, the wheat crop, while only 1 , var nivale appears to be present on turf grass and rye.

Despite the range of variation among the isolates of $M$ nivale tested, their pathogenicity on seedlings was not related to any of the criteria used to discriminate groups among the population. The variation of DI was similar in both varieties, and no difference in aggressiveness according to the host of origin was observed. Because all isolates are pathogenic on wheat and exhibit variation for aggressiveness, isolates of either type may be used to screen variability of wheat for resistance against $M$ nivale, provided that the isolate chosen is highly aggressive and produces the large numbers of conidia necessary to carry out artificial inoculation. It may be interesting to examine a larger number of turf grass and rye isolates in order to compare their pathogenicity on wheat and turf grass and to confirm that these isolates are all var nivale and are all heterothallic.

This study has provided further evidence of variation within $M$ nivale and supports the presence of at least 2 groups among populations of $M$ nivale. It has been demonstrated that considerable variation exists within the nivale group whereas the level of diversity is much lower within the majus group. A more detailed study of the nivale group is now required to determine the 
mechanisms by which polymorphism is generated and maintained. Homothallic and apparently heterothallic isolates were present in both groups. Further work is required to determine whether mating groups exist within the heterothallic isolates, or whether isolates are merely unable to produce perithecia under the culture conditions provided.

\section{ACKNOWLEDGMENTS}

We wish to thank $\mathrm{G}$ Capron for technical assistance and contribution to this work. We are also indebted to D Gindrat (SFRA, Changins Switzerland), MP Latorse (Rhône-Poulenc Agrochimie, Lyon, France), H Maraite (Univ Catholique de Louvains, Belgium), H Nirenberg (BBA Berlin, Germany), and Pronczuk (IHAR, Radzików, Poland) for providing isolates from their collections. The work of the pathology section of the Cereals Department is supported by the Ministry of Agriculture, Fisheries and Food, UK.

\section{REFERENCES}

Bruehl GW (1982) Developing wheats resistant to snow mold in Washington State. Plant Dis 66, 1090-1095

Cassini R (1981) Fusarium diseases of cereals in Western Europe. In: Fusarium, Diseases, Biology and Taxonomy (PE Nelson, TA Toussoun, RJ Cook, eds) Pennsylvania State Univ Press, PA, USA, 56-63

Cook RJ (1981) Fusarium diseases of wheat and other small grains in North America. In: Fusarium, Diseases, Biology and Taxonomy (PE Nelson, TA Toussoun, RJ Cook, eds) Pennsylvania State Univ Press, PA, USA, 39-52

Daamen RA, Langerak CJ, Stol W (1991) Surveys of cereal diseases and pests in the Netherlands. 3 . Monographella nivalis and Fusarium spp in winter wheat fields and seed lots. Neth J Plant Pathol 97, 105-114

Duben J, Fehrmann H (1979) Vorkommen und Pathogenität von Fusarium-Arten an Winterweizen in der Bundesrepublik Deutschland. I. Artenspektrum und Jahrzeitliche Sukzession and der Halmbasis. Z Pflanzenkr Pflanenschutz 86, 638-652

Gams W, Müller E (1980) Conidiogenesis of Fusarium nivale and Rhynchosporium oryzae and its taxonomic implications. Neth J Plant Pathol 86, 45-53

Gerlach W, Nirenberg H (1982) The Genus Fusarium - A Pictorial Atlas. Paul Verlag, Berlin, Germany

Harris JR (1986) The association of Monographella nivalis with cereal root disease in Southern Australia. Aust Plant Pathol 15, 35-38

Laemmli UK (1970) Cleavage of structural proteins during assembly of the head of bacteriophage T4. Nature (Lond) 227, 680-685
Lees A, Nicholson P, Rezanoor HN, Parry DW (1995) Analysis of variation within Microdochium nivale from wheat, evidence for a distinct sub-group. Mycol Res 99, 103-109

Litschko L, Burpee LL (1987) Variation among isolates of Microdochium nivale collected from wheat and turfgrasses. Trans Br Mycol Soc 89, 252-256

Litschko LD, Burpee LL, Goulty LG, Hunt LA, McKersie $B D$ (1988) An evaluation of winter wheat for resistance to the snow mold fungi Microdochium nivale (Fr) Samu and Hall and Typhula ishikariensis Imai. Can Plant Dis Survey 68, 161-168

Maurin N, Chénet I (1993) Espèces de Fusarium présentes dans les cultures de céréales en France : résultats d'enquête sur la campagne 1991-1992. Phytoma 453, 20-22

Miedaner T, Höxter H, Geiger HH (1993) Development of a resistance test for winter rye to snow mold (Microdochium nivale) under controlled environment conditions in regard to field inoculations. Can J Both $71,136-144$

Nirenberg HI (1981) A simplified method for identifying Fusarium spp occurring on wheat. Can J Both 59, 1599-1609

O'Dell M, Wolfe MS, Flavell RB, Simpson CG, Summers RW (1989) Molecular variation in populations of Erysiphe graminis on barley, oats and rye. Plant Physiol 38, 340-351

Ou SH (1972) Rices Diseases. Kew, Commonwealth Mycological Institute, UK

Parry DW (1990) The incidence of Fusarium spp in the stem bases of selected crops of winter wheat in the Midlands, UK. Plant Pathol 39, 619-622

Pettitt TR, Parry DW, Polley RW (1993) Improved estimation of the incidence of Microdochium nivale in winter wheat stems in England and Wales, during 1992, by use of benomyl agar. Mycol Res 97, 11721174

Siciliano MJ, Shaw CR (1976) Separation and visualisation of enzymes on gels. In: Chromatographic and Electrophoretic Techniques (I Smith, ed), Williams Heinemann Medical Books Ltd, London, UK, vol 2, 185-209

Smith JD (1983) Fusarium nivale (Gerlachia nivalis) from cereals and grasses: is it the same fungus? Can Plant Dis Survey 63, 25-26

Somé A, Tivoli B (1993) Fusarium spp from potato: polymorphism of esterase phenotypes on polyacrylamide gel electrophoresis. agronomie 13, 637-649

Wollenweber HW, Reinking OA (1935) Die Fusarien, ihre Beschreibung, Schadwirkung und Bekämpfung. Paul Parey, Berlin, Germany

White TJ, Bruns T, Lee S, Taylor J (1990) Amplification and direct sequencing of fungal ribosomal RNA genes for phylogenetics. In: PCR Protocols. A Guide to Methods and Applications (MA Innis, DH Gelfand, JJ Sninsky, TJ White, eds), Acad Press, San Diego, CA, USA, 315-322 